Article

\title{
The Study of Nation and Patria as Communities of Identity: Theory, Historiography, and Methodology from the Spanish Case
}

\author{
Pablo Sánchez León
}

Cham Humanities Center, Nova University of Lisbon, 1069-061 Lisbon, Portugal; psleon@fcsh.unl.pt

Received: 4 December 2019; Accepted: 27 February 2020; Published: 2 March 2020

\begin{abstract}
This article argues for a renovation in the study of nationalism by addressing the issue of the rationality underlying the decisions by citizens willing to leave their homelands. From the example of unforced exiles from the 1939 Republican diaspora (and inner exiles as well), the text starts with providing a theory of disidentification from a nation for the sake of civic commitment. Having shown the relevance of jointly studying the language of nation and patria, it focuses on Spanish post-Francoist historiography of the Early modern period for showing its unbalanced account of discourse revolving around patria in favor of that of nation. Thereafter, it provides a comparative overview of the scholarly interest in patriotism in modern history as depending on different national trajectories of political culture. Finally, it claims a methodological reorientation in the study of nationalism and patriotism by distinguishing between nation and patria as terms, as concepts, and as analytical categories defining distinctive collective identities.
\end{abstract}

Keywords: nation; patria (fatherland); identity; patriotism; nationalism; citizenship; deliberation; self-government; Spain; early modern history; modern history; historiography

To my friend, brother, and American in-sile Miguel Sánchez

\section{Exile as Dilemma to National Identity}

2019 has commemorated the 80th anniversary of the end of the so-called Civil War extended between July 1936 and March 1939, a transcendental process in Modern History that put an end to the democratic republic established in Spain in 1931. In this occasion celebrations have centered around a dramatic sequel to the suppression of liberties resulting from the war: Exile. ${ }^{1}$ The Spanish exile of 1939 was probably unprecedented in its scope and span: Compared to other migrations and forced displacements of populations in its nearest context following World War I, the citizens who abandoned Spain in 1939 were not ethnic or confessional minorities neither belonged to the intellectual elite but actually came from a wide variety of economic, social, and cultural backgrounds (estimates for different national cases from the first third of 20th century in (Kaya 2002, pp. 17-18); on its sociological scope (Caudet 2005, pp. 235-73)). Yet this singular profile only highlights a feature common to political-ideological conflicts in modern societies: That among the consequences of the suppression of liberties one is the decision by average citizens of abandoning a national state.

In effect, a considerable proportion of the people who decide to exile do not flee form the destruction provoked by war and civil confrontation, but rather from its expected political and institutional results. In the particular case of 1939 Spain, it is unquestionable that among those who

1 Information on the creation of a commission for the commemoration of the Republican exile, in https://www.mjusticia.gob. es/cs/Satellite/Portal/es/ministerio/gabinete-comunicacion/noticias-ministerio/comision-interministerial. 
left their home-country many were escaping from the duress they foresaw after the victory of Franco's troops; however, the fear of repression does not exhaust motivations for exile: There is evidence of Spanish Republican exiles who considered that, should they stay, their physical and moral integrity or their legal status would not be endangered. ${ }^{2}$ By contrast, among the defeated who remained the majority feared they would suffer repression by the authorities of Franco's regime, which was often the case through harassment, imprisonment, and even execution. Overall, the different courses of action between the two groups do not seem to have depended only on the supply of information, neither can be just pinned on the distribution of resources and opportunities nor were brought about from weighing expectations against risks: In a context of "total war" as the Spanish 1936-39 conflict (Chickering 2008), it was extremely hazardous to anticipate the consequences of decisions.

The phenomenon of exile allows signaling the presence of individuals willing to leave their country because they do not retain a sense of belonging; in other words, they have stopped feeling identified with their community of birth and socialization. The same applies as well to those who do not leave their country but stay in a sort of "inner exile", "a mental rather than material condition" which "alienates some people from others and their ways of living" (Ilie 1981, p. 7), making them carry an existence as foreigners in their own homeland. In the case of Spain after 1939, many of those who had lived under the democratic liberties of the Second Republic experienced an utter disaffection towards the values, symbols, and rituals of the Francoist Nuevo Estado: Actually the term "inner exile", also referred to as "in-sile" to define the experiences of exclusion suffered by many citizens (Gómez Bravo 2013), was actually coined during Franco's protracted regime (Salabert 1988, pp. 9-10).

To my knowledge, implications of these two mutually interrelated phenomena have not been much addressed in studies on national identity and nationalism in general, and particularly by Spanish specialists. This article tries both to question and enrich the scholarly approach to the issue of belonging in modern communities. It does so first, by providing theoretical reflection on the rationality underlying disidentification with a national community to the point of, either willing to leave the country that grants fundamental rights, or staying but feeling a stranger to it. Drawing from psychosocial and historical perspectives on the rise of modern citizenship, I distinguish between nation and patria as communities of identity, and theorize on patriotism as a distinctive kind of political sentiment that overflows the semantics of nationalism. The text then addresses the way Spanish Post-Francoist historiography has been dealing with the study of the terminology and the fields of nationalism and patriotism. I focus on the historiography of the Early modern period to signal the unbalanced treatment of these two terms and go ahead relating the scholarly preferences among historians to the historical trajectories of modern political cultures in different countries. Finally, I offer a methodological critique to conventional hermeneutics on the language of patria and propose an alternative methodology for distinguishing between words, concepts, and categories relevant for the study of patriotism as a collective identity.

\section{Disengaging from National Identity Out of Civic Commitment}

Among the topics of Spanish post-war culture one that stands out is a polemic on the nature of the Spanish nation engaged by two intellectuals from exile, Claudio Sánchez-Albornoz and Américo Castro (Morales Moya 2013). While the former endorsed an ontological and essentialist conception of national identity, the latter argued that Spanishness was a historical product collectively built through cultural and political processes, a perspective that has eventually become commonsensical in other national historiographies (see for Britain, Colley 1992). In the wake of that debate, Castro published

2 One relevant example is Claudio Sánchez-Albornoz, minister of State under the Second Republic in 1933. He left Spain during the war but argued he did so freely and not out of fear of repression but rather of disillusion with his compatriots, an argument that prompted reaction from the then President of the Republic Manuel Azaña, who tagged him an exile for convenience (Azaña 1978, vol. II, pp. 226-27, 236). Eventually, Sánchez-Albornoz would be appointed President of the Government of the Republic between 1962 and 1971. 
the essay Los españoles: Cómo llegaron a serlo [Spaniards, how they became] (Castro 1965), from which title a complementary question can be raised: How Spaniards, or members of whatever other nation, have ceased to belong, in the sense of feeling themselves detached from their original nation.

Addressing this issue implies acknowledging that a community may deny recognition to individuals, but its members may as well end up neglecting their community of belonging (Pizzorno 1986). This general statement applies, for example, to dual national identities in stateless nations whenever people start rejecting one at the cost of another (see on the case of current Catalonia, (Oller et al. 2019)). Accounting for national disidentification requires further specification, though, since nations are at once a referent of individual and collective identity and the communitarian foundation of the modern state (Jessop 2011). Accordingly, disidentification with a nation may entail also rejecting the rights derived from naturalization as granted by a state, a sequel deeply affecting the condition of citizenship.

Normally, though, denaturalization takes place as part of a wider process of claiming re-naturalization in another nation state. From a psychosocial perspective, this push-and-pull logic can be formulated arguing that disidentification from a community implies re-identifying with another, otherwise the individual will be exposed to lose an essential emotional attachment and risk falling into anomy (Durkheim 1951; Merton 1938). In the case of transnational migrants and forced exiles, the alternative community is usually a concurring nation, and so naturalization in a different nation state, aside from providing with a sense of belonging, gives access to its appertaining rights. The abovementioned phenomena of unforced exile and of inner exile, however, foreclose reducing the issue to a choice between national communities.

As shown in the case of 1939 Spain, Republican exiles did not leave willing to be naturalized in another nation-state; rather, they flew out as they became aware their citizen rights would not continue to be upheld in their country of origin. Such awareness involves a kind of reflectivity distinctive from the acquisition of another national identity, which is normally the effect of rather unpolitical (Esposito 2011) socialization in cultural habits, symbols, and rituals: Instead, involved in the kind of decision epitomized by exiles there is deliberation about political issues, a procedure inherent to modern citizenship (Mouffe 1999). On the other hand, claiming naturalization in a national state may be neither the cause nor the consequence of developing a sense of belonging: As embodied by Spanish Republican exiled who failed to adapt to the hosting national cultures (Abellán 2001, pp. 85-109), deliberation leading to exile does not necessarily entail re-identifying with another national community; much the same applies to "in-silers" who do not recreate bonds with the national state by which they feel oppressed.

The example of unforced exiles reveals limitations in conventional definitions of nation and national identity. Across the specialized literature there is a contrast between two conceptions of nation, as either founded on cultural, given referents or on political, voluntary traits (Kohn 1946; Smith 1991; critical overviews in Renaut 1991; Brubaker 1999). The experience of exiles calls attention towards allegiance to a community in exchange for commitment to political, but not voluntary referents. Deliberation is certainly involved in the decision of breaking ties with the homeland nation; yet, it only takes place after a process of disengagement or disidentification that cannot be explained in instrumental or strategic terms: As much as inner exile, unforced exile is rather an expressive kind of action (Hargreaves-Heap 2001) through which the citizen conveys the value he/she allocates to referents that provide with an identity beyond gender, class, and race-and beyond the conventional definitions of nation as well. The commitment of willing exiles is towards a distinctively civic community which, by upholding freedom and the exercise of rights, provides with a sense of belonging and well-being; and this sharing in a collective identity is priceless to the point that, under conditions, the commitment may be unlimited.

In the western tradition there is acknowledgment of such community: The fatherland or patria, and of its related sentiment-patriotism, as "primarily a political passion based on the experience of citizenship, and not on common pre-political elements derived from having been born in the same territory, from belonging to the same race, speaking the same language, worshipping the same deities or having the same customs" (Viroli 2001, p. 7). Although patriotism has been the object of 
historical studies and analytical reflections (see readers in (Primoratz 2002); (Bar-Tal and Staub 1999); a philosophical approach in (MacIntyre 1995)), a narrow focus on its demand for sacrifice-as inspired by the expression "To die for the fatherland" - has contributed to discredit this political sentiment as a sort of cultural transfer from ancient times to be blamed for much of the inhuman warfare and the rather lurid cult towards "the fallen" in modern history (Koselleck 2012; Tamir 1997). The example of unforced and inner exiles provides with a different perspective that reinserts patriotism into the sphere of citizenship.

Despite being founded on civic values, however, as collective identity patriotism should not be confused with cosmopolitanism understood as a kind of rational allegiance to unembedded institutions and decontextualized values, no matter how political they may be (Nussbaum 1989, 2019). Much like other citizens exposed to political backlashes in modern nation states, the Spanish exiles and "in-siles" of 1939 were not committed to a supranational ideal of communitarian political life, nor were just moved by universalist mantras: Rather, they were either leaving behind or longing for the formerly free community of the Spanish Republic, to which they felt a subjective attachment and an emotional commitment independent from its foundation in universal and progressive values (see a general statement on this in Taylor 1989).

As embodied by self-persuaded exiles, patriotism is better grasped from a historical perspective as being rooted in "the political institutions and the particular way of life of the republic" (Viroli 1995, p. 37). In this sense, patria stands for an "imagined community" as powerful as the nation, yet one distinctively founded on civic referents the relevance of which marks itself at specific crossroads in the history of citizenship. Under "normal" political conditions, however, patria is a source of identity usually intertwining with nation. It is then no wonder that nationalism and patriotism own a scholarly tradition of being addressed in tandem (Huizinga 1959; Viroli 1995).

\section{The Study of Patriotism in Spanish Historiography}

It is quite striking that the commemoration of the Spanish exile of 1939 has not fashioned reflection on the disidentification with the national community experienced by citizens who resented from the demise of democracy after the war. Equally eloquent of the state-of-the-art of Spanish post-Francoist intellectual production is the fact that the 2019 Essay Prize [Premio Nacional de Ensayo] has been awarded to a work on Spanish nationalism (see news in Huete 2019, and the essay in Núñez-Seixas 2018). Notwithstanding the relevance of the study, the decision is revealing of scholarly and cultural preferences in Spanish democracy, a profile underwritten by the awards granted also in the years 1998, 2002, and 2008 to essays on Spanish national identity or regional nationalist identities (Juaristi 1997; Álvarez Junco 2001; and Beramendi 2007, respectively) against not a single one devoted to the issues of fatherland, patriotism, or even exile.

True enough, national identity and nationalism are also star topics elsewhere worldwide, but in Spain there are further reasons which help explain such an intensive interest in nation-building, national identities, and the rise of nationalist ideologies: The relevance of national identities of regional scope in post-Francoist democracy. Yet, the influence of nationalist outlooks on the national political agenda should in principle have also stimulated interest in reflecting upon other kinds of bonding and communities of belonging in modern societies in order to meet an extended demand among citizens who feel uneasy with the social and political over-presence of nationalist identities.

This deficit points especially towards historians. The past has transmitted enough traces of political identities primarily built on communitarian referents other than ethnical, confessional, or cultural (Prak 2018). More in particular, the semantics of patria has been sharing in Western history from the acquisition of the language of politics since the Renaissance onwards (Viroli 1992). Increasingly embedded in the juridical language of the Old Regime, in many principalities of Europe the language of patria contributed to uphold political rights, despite their being often recognized not to citizens but to subjects (Lessafer 2001, pp. 200-1). Moreover, partially re-signified from its original meaning in classical Antiquity (Viroli 1995, pp. 18-22), patria conformed one of the nuclear tropes in the tradition of republican Humanism, a discursive repertoire on civic identity as 
a moral virtue essential for the maintenance of polities founded on self-government (Pocock 1975). Throughout the Early Modern period, a language of patria provided with interpretive resources for disidentification with communities of belonging, especially to dwellers of self-governed cities whenever these failed to assure them a dignified civic life. In contrast, the hegemonic vision is that nations as communities of adscription do not reckon such prominent pedigree before the 19th century, being rather a modern phenomenon ((Anderson 1991); an overview of debates from the opposite view in (Smith 2000, pp. 27-51)) deeply intertwined with the rise of modern states while not necessarily with the establishment of political rights.

Spanish historiography is not balanced in its approach to this issue, though: Perspectives relating to national identity are overwhelming, even in scholarly studies on the Early modern period. Part of this situation may be justified by the available historical record: Indeed, overarching confessional referents hegemonized the language of republican civic Humanism in the territorial domains of the Habsburg dynasty (Fernández Albaladejo 1997), even reaching into an explicitly anti-republican rhetoric. However, there are other reasons involved, which have to do with the peculiar relations of modern Spanish scholars with the issue of nation and the building of citizenship, to the point that their addressing of these issues reveals an unsolved tension for historizing the nation as community of belonging.

In general, narratives on the national community are founded on a mythification of the nation as an intemporal community or of remote origin, and Spain is no exception (Wulff 2003). What is more specific to modern Spanish historiography is precisely the opposite: A recurrent reference to datable historical events for the establishment of the nation. This epistemological criterion derives in turn from the heritage of a narrative framework mimicking "sacred history": In fact, the two usual historical dates alternatively settled for defining the nation have been the conversion to Christianity by Visigoth king Recaredo in the 6th century AD, and the dynastic unification of the kingdoms of Castile and Aragon under kings Isabella and Ferdinand in the wake of the invasion of the Muslim Kingdom of Granada and the expulsion of the Jews in 1492 (Pérez Vejo 2015; Boyd 1997, pp. 99-121). Far from being superseded with the demise of the Old Regime, this shaping of national history through confessional lines ended up framing Liberal historiography, which further conflated dynastic and religious unification with the forging of the nation, a metanarrative that gathered momentum under Franco's regime when, in spite of their logical contradictions, both essentialist, ahistorical, and chronological tropes tended to be fused in conventional historical accounts.

Certainly, this whole narrative framework was put into question in the wake of the transition to democracy, displaced by a new chronology that traces the starting of the national community to the promulgation of the 1812 Constitution; however, the quest for settling a fully alternative historiography has not been rounded up by Spanish post-Francoist historians. A goal such reaches beyond questioning the mythical foundation of the inherited national history; yet it cannot either reduce itself to agreeing on alternative chronologies: It also demands re-inserting the whole narrative on the national past into a historical frame shaped by the building of citizenship.

This is far from having been achieved. In its place, what we have are usually accounts of the nation as a historical entity along with the persistence of ontological assumptions. In fact, there are readings of the past that, lingering on Francoist ideals of the nation as both diverse and united (Núñez Seixas 2014), still take for granted that Spain is an essentially homogeneous and enduring object of study to be addressed from prehistoric times to the present (García de Cortázar 1994); other post-Francoist specialists have on their part tried to rewrite genealogies of the nation reaching back to the Middle Ages (Valdeón Baruque 1982). True enough, there are approaches much more sensitive to historization and providing with prospective accounts. Among these, there stands out a literature on early modern "nation-ism" (nacionismo) defined in contrast to modern nationalism, as a discourse that addressed the nation as community of belonging through the Early modern period. In line with previous trends elsewhere (Armstrong 1982), this literature has aptly contributed to distinguish "the nation before the nation-state" (Fernández Albaladejo 2007) by interpreting the meaningful traces as both a discursive and identity phenomenon prior to the French Revolution of 
1789 and the Spanish constitutional crisis of 1808 , a period dominated by patrimonial monarchies but also hosting independent republics.

Additionally, yet even this refined thematic line still expresses the priorities among the Spanish historians from the generation who witnessed the establishment of democracy. In general, their interest in studying the rhetoric of nation and nationality before modernity is not matched by a similar attention to the communities of belonging that figured as hegemonic in the context of emergence of "nationist" discourse (see an example in Ballester Rodríguez 2010). Overall, early modern nacionismo is not weighed against the contribution of other territorial identities through the Old Regime. In consequence, the approach reproduces the teleology inherent to traditional historiography, somehow projecting that modern nationalism must have come after pre-modern "nationism".

One of the interesting novelties of 2019 is precisely a book that explicitly deals with the way Spanish historiography has been addressing the nation as a topic. The work was first published in English as Speaking of Spain (Feros 2017), a title that wanted to convey the relevance of a focus on the intellectual debates around the imagination and lexicon of the nation that pervaded the Early modern period. Instead, the book has been published in Spanish as Antes de España (Before Spain (Feros 2019)), an alternative title bearing witness that still in the 21st century critical historiography needs to be militant on the issue of the chronology of the Spanish nation. Other than that, the work exemplifies both the possibilities and the limits of post-Francoist historiography in overcoming stereotypes and mythifications on the issue of nation.

National identity before the establishment of the nation as political community is the topic of a work that plays out as both a monograph, a state-of-the-art, and an essay for the wider public. The book is to begin with remarkable in relating discourse on the political community with that on social groupings and especially on the ethnic and religious minorities that shaped the societies of the Hispanic Old Regime; in effect, in a rather unusual approach, Feros addresses the status of the nation vis-à-vis other infra-national referents of identity. Moreover, by integrating the transatlantic dimension of the Hispanic monarchy, the essay provides with a most uncontroversial conclusion, namely, that the only territory of the empire in which peninsular vassals were known as "Spanish" was the New World. By contrast, in the peninsula a Spanish identity owned very limited cultural status, not to mention any legal relevance-general references to the subjects of the Hispanic monarchy as a whole being normally deployed in discourse elaborated by foreigners.

Throughout the early modern era there was a "nationist" discourse in Hispanic culture, but as shown in Feros's synthesis elaborated from numbers of critically selected researches, the overarching community of belonging remained that of the so-called Catholic Monarchy and its divine right of kings. According to this author, a Spanish nation cannot be spoken of even for the 18th century; and still then, in spite of the legal and institutional homogeneization following the suppression of the self-governing traditions in Catalonia, the cultural basis for a national community was ultimately constrained by Bourbon dynastic legitimacy. As for the previous centuries, the polycentric matrix of Habsburg rules established different relations with their diverse European and overseas possessions (Cardim et al. 2012), which implied giving recognition to subjects who did not define themselves as "Spanish" but rather primarily as Catalan, Aragonese, Valencian, Navarrean, etc. protected by specific privileged and territorial rights.

Feros's book is also relevant in addressing the language of patria in the making of peninsular collective identities before modern history, a topic revealing of the current state of scholarly studies. Among post-Francoist historians of the Early modern period there are specialists who have committed themselves to historize the meanings and usages of patria in discourse - some even offering comparative analyses of the semantics of nation and patria in the various peninsular principalities (Gil Pujol 2004). As opposed to studies on "nationism", however, these do not depart from a distinction between early modern and later definitions of patria, assuming rather than probing that the language of patria has not experienced relevant historical changes affecting the meaning of patriotism as a political sentiment of belonging.

On top of this, among younger generations of historians a growing interest on republicanism as a transnational variety of political thought has been developed at the cost of properly specifying the 
case for the Iberian peninsula. In spite of its high degree of urbanization throughout the 16th century (Sánchez León 2001, 2002), towns and cities in the Crown of Castile did not provide urban dwellers with a status as citizens with political rights; they were rather defined at once as vecinos (neighbours) and subjects to the king (Carzolio 2002; Herzog 2003). At the same time, the division of urban society by estates impeded the definition of a single legal community, while the hegemony of confessional identities constrained the emergence of autonomous political values (Sánchez León 2002, 2007). Overall, the cities of Castile did not result from the fragmentation of sovereignty but rather reflected a hierarchy of jurisdictional powers crowned by the monarch (Fernández Albaladejo 2017, p. 665). In such a context, the development of republican discourse was no indicator of the rise of patriotic identities but rather reflected the transnational profile acquired by Humanist rhetoric.

Urban political culture was certainly different in the Crown of Aragon, a territory hosting several important ports such as Barcelona or Valencia with a tradition of urban self-government and citizenship statuses, a contrast that should have encouraged comparisons between the two kingdoms and other territories in Europe both within and beyond the domains of the Habsburg dynasty. Instead, recent approaches to civic Humanism as offered by Spanish historians have argued for a single frame of republican identities common to the greater cities and towns of the European continent including the Iberian peninsula irrespective of their social, political, and cultural differences (Herrero 2017). Inherent to this trend seems to be a "kind of faked need to convey a republican DNA" to the Southern part of the continent (Fernández Albaladejo 2017, p. 666) that not only degrades the specificity of the republican tradition but also confounds citizenship, vecindad, and the more extended condition of subject along the Old Regime; as a result, the complex historical relation between civic culture, patria, and patriotism is taken for granted instead of being problematized.

Summarizing, even when studying the Early modern period Spanish historiography devotes itself to the topic of the nation at the cost of patria and its related sentiment of patriotism. However, this preference in post-Francoist scholarly studies is induced by a deeper deficit in historical narratives on the longer-term building of citizenship.

\section{The Ebbs and Tides of Patriotism as Collective Identity in Modern History}

It may be argued that Spanish historiography on the nation is not so uncommon: After all, in other academic environments reflection and research on the topic occupies an outstanding place. However, behind formal analogies there are distinctive political cultures that need to be sorted out in order to comparatively understand the changing relations in the semantics of nation and patria, especially when dealing with modern history.

One main difference between Spain and other Western democracies such as Great Britain, France, or the United States is that these latter have not witnessed the suppression of basic constitutional rights upholding the exercise of citizenship. In terms of the example above, these democracies have not exposed their citizens to the dilemma of Spanish Republican exiles. Accordingly, in the political cultures of those well-established democracies discourse on national identity is not originally disengaged from the narrative on citizenship building. This has not prevented these countries from distorting the republican tradition, however, by embarking in imperialist ventures that deeply affected their political cultures. In effect, the rise of imperialism brought about a tension to the inherited language of patria, which was usually reshaped into the semantics of civilization (see Mazlish 2004, pp. 1-48) and often subsumed under a rhetoric of militarism (Koselleck 2012). Accordingly, by the turn of the 19th century, the struggle for hegemony among imperial metropolises eventually had fused nationalism and patriotism in a single discourse (see an insightful analysis written in the context of World War I in Veblen 1917, pp. 31-76, “On the Nature and Uses of Patriotism"), a trend that got embedded during the so-called Second Thirty Year's War of 1914-18 (Traverso 2016) as modern citizenship was challenged by the expansion of both reactionary nationalist and aggressive militaristic ideologies.

After World War II, the subaltern discursive status of patriotism was sealed in historical narrative. With the rise of "social history" the focus of attention became the classes and other group identities 
produced by economic structures (Cabrera 2004), an emphasis placed at the cost of specifying the historical relations between overarching national or civic-patriotic identities. On their part, in Southern European and Latin American countries experiencing a belated or intermittent democratization social history strangled the potential demand for a narrative on the long-term construction of citizenship; and while the nation-state was perceived as the natural type of modern political community, the account of the historical intertwinements of patriotism and nationalism was sidelined.

In this scholarly context, the first wave of studies on the nation and nationalism took place along the fall of Soviet Socialism at the end of the 1980s, a process that was saluted as the ultimate triumph of nationalism as the ideology of modern political communities. Benedict Anderson, in a seminal work greatly inspiring this and subsequent academic fashions on national identity, underlined that "since World War II every successful revolution has defined itself in national terms", which he characterized as "a territorial and social space inherited from the prerevolutionary past" (Anderson 1991, p. 2). Anderson questioned the Marxist theory of class struggle as a sufficient basis for the legitimacy of socialist regimes. However, his statement did not result from a comparative study on nationalism and patriotism in the official discourse of Soviet regimes; and yet their self-definition as "popular democracies" strongly suggests that modern social revolutions have also been harbinger for patria as alternative political community to nation.

By the end of the 20th century, with the creation of the European Union and the expansion of globalization, nation-states have been exposed to growing pressure: The rise of nationalist outlooks is recurrently related to the emergence of new supranational entities constraining national sovereignty while increasing transnational exchanges of capital and people (Banks and Gingrich 2006). This trend has subsumed even more the language of patria into that of nation in historical narratives as much as political discourse at large. One example of the trend is the opening of the Olympic Games in London in 2012, designed by film director Daniel Boyle as a series of episodes amounting to a synthesis of the national history of the host country, Great Britain: The scenes in the show stressed that the island was "the birthplace of the Industrial Revolution and the workshop of the world", which made that historical experience certainly "hellish" but also "awesome achievements" have to be acknowledged not only in "engineering and manufacturing" but also in "big steps towards democracy, the collective selfhelp of the labour movement, and the struggle for the emancipations of women and other social revolutions" (Bryant 2015, p. 3). In the proposed narrative, this trajectory gathers momentum in the creation of the National Health Service after World War II; yet, in the guide for the event written by the author, this relevant citizenship conquest features as "the institution which more than any other unites our nation" (Bryant 2015, p. 10). Another example from the side of patriotic discourse has to do with the protectionist policies enacted by President of the United States Donald Trump. These measures have been shaped in an anti-globalization rhetoric in which patriotic identity is openly distorted as neo-imperialist national grandeur (Johnson 2004); as declared by Trump at the United Nations: "Greatness is only realised by the will and devotion of patriots" (Borger 2019).

The examples underwrite that patriotism is recurrently endangered by both nationalist and imperial-militaristic rhetoric, the combination of which makes difficult even to critically isolate it in discourse as a distinctive political identity. On the other hand, however, they also point to the enduring resilience of the language of patria as both a semantic heritage bridging between the evolution of national identities and the dynamics of citizenship, and a substratum resurfacing with variable autonomy depending on circumstances. One such context is the public sphere of early 20th-century Spain, which has witnessed a recovery of the lexicon of patria, staged by the political formation Unidas Podemos (Sola and Rendueles 2018) in the wake of the so-called 15M, the 2011 citizen protest that broadcasted collective consciousness of a crisis in post-Francoist democracy (Fernández Savater 2019).

The entry of patria into discourse in current Spanish political culture has been instrumental in confronting the hegemonic discourse on nation, and especially in opposing nationalist "españolista" identities. In turn, its semantics draw from previous developments in Latin American political cultures (Baron and Díaz 2016), where it has been enhanced by two historical discursive veins: An initial 
republicanism shaping citizenship building through the process of colonial independence in the early 19th century (Pérez Vejo 2015); and a recurrent anti-imperialist ideology developed already in the 19th century and especially throughout the 20th century (Gobat 2013; Knight 2008; MacPherson 2006). However, their eventual blending into the scheme of "dependency theory" (Cardoso and Faletto 1979), has skewed this dual genealogy of patria towards the latter semantics. This helps explains its appealing to Left-wing Spanish ideological stances sensitive to international threats to sovereign integrity in the wake of Spain's adjustment to the requirements of balanced budget imposed by the European Union.

The case of early 21st-century Spain confirms that in a world straddled by supranational trends, the discourse of patria is being reduced to the defense of sovereignty, a status that renders it vulnerable to nationalist rhetoric. In the western tradition of political philosophy, however, patriotic identity was reasonably expected not only in response to external attacks on the institutions of self-government by foreign powers, but was also against internal menaces by the enemies of political liberties. This dual dimension was fragmented already during the 18th century, however, following the end of religious wars and in the wake of the political reforms brought about by the Enlightenment. In effect, with the rise of standing, conscript armies, civic commitment to the banner of Pro patria mori was put at the service of the building of nation-states (Viroli 1995, pp. 140-60), while the rise of the public sphere disseminated competitive ideologies capable of fueling enthusiasm (Moscoso and León 2017). According to Reinhard Koselleck, patriotism was the first among modern concepts of movement (ending in -ism), coined before those of nationalism or imperialism (Koselleck 2012); however, in entering modern history these latter seem to have recurrently conditioned the integrity of the former. Additionally, yet, as the example of unforced exiles keeps reminding, disengagement from national communities for the sake of a commitment to civic values-patriotism-is no less a recurrent experience of modern citizens.

\section{Nationalism and Patriotism in Spanish Modern History: A Methodological Bedrock}

The fate of unforced and inner exiles also reveals that the triggering of patriotic attitudes and identities relates closely to contexts of civil war. Recent studies on the history of this concept have extended the scope of civil war to comprise all forms of conflicts, from coup d'états to revolutions, brought about by struggles between defenders and opponents to political freedoms (Armitage 2015, 2017). Moreover, there is a growing understanding of modern history as a succession of states of exception imposed against the will to self-government by deliberative citizens (Agamben 2005). These trends will probably spark interest on the issue of patriotism in the coming future.

So far, modern Spain appears as an outstanding case for addressing the complex relations between the languages of patria/nation and the sentiments of patriotism/nationalism as developed on the background of civil wars. Already as early as in 1808, the response to Napoleonic invasion became at once a crucible of the national community and a source of civic identities both among elites and commoners willing to curtail the unbridled powers of the Old Regime, a process that in its turn fostered a relative interchangeability between nation and patria in discourse (Vilar 1982; Aymes 2004). Interestingly enough, the memory of the so-called War of Independence defined it also as a civil war engaged between defenders and opponents of a constituent proves (Sánchez León 2008), while the return to absolutist rule in 1814 produced the first wave of political exiles in modern Spanish history (Simal 2012), some among which decided to leave the country at free will. ${ }^{3}$

Overall, Spanish Liberalism produced a definition of the nation as sovereign subject (Portillo 2000) that, although actually combining Catholic and republican semantics, eventually affected the status of patria in the repertoire of linguistic resources. To begin with, it allowed for its appropriation by opponents to Liberal Constitutions, who eventually deployed the word for referring to their imagined

3 One relevant example was the reputed writer and ideologist José Blanco White, who relinquished his nationality out of a deep disenchantment with Spanish traditional culture at large; see a profile following my interpretation on unforced exile in Loureiro (2000, pp. 31-63). 
community, alien, and even hostile to citizenship as it was, placing it in their banner "Dios, Patria, Rey" (God, fatherland, King (Canal 2000)). Moreover, the outbreak in 1833 of a military conflict between Liberals and Traditionalists explicitly labeled as a civil war further contributed to identify the nation with modern liberties at the cost of patria (Varela 1994). On their part, the growing role of the military in the resolution of political conflicts contributed to further drain the concept of patria of civic content. On top of this, the repression of anticolonial struggles in the Caribe and later the starting of neo-colonial adventures in Africa insufflated discourse with militaristic rhetoric, a pattern similar to other Western nation-states, with the singularity that in Spain the frontiers between colonies and metropolis was recurrently blurred both in repressive techniques and discourse (an example in (Godicheau 2014); a general overview in comparative perspective in (Fradera 2015)).

In sum, in modern Spanish discourse the terminologies on nation and on patria have tended to be interchangeable; however, both usually refer to the semantic field of the former. Instead of being reflected on, this phenomenon is rather uncritically replicated in historiography. As in the scholarly production on the Early modern period, efforts to approach the two lexicons in comparative perspective are scant (one example is offered in (Fernández Sebastián 2005)). In general, research on modern history not only blatantly focuses on the topic of the nation but also takes for granted the utterances of patria as synonymous, and conflates patriotism with nationalism, a practice that bears consequences on the overall narrative of the period.

As an example relevant for the case, the 1936-39 war has been interpreted as founded in opposing, yet symmetrical nationalist identities on the two sides of combatants (Núñez Seixas 2006). This view fits fairly well for the Francoist side, but not so well for the defenders of Republican legitimacy. This latter certainly defined itself as a nation, and deployed a mobilizing rhetoric in accordance; however, it was also founded on reference to a self-governed political community, a difference that is at the basis of the dilemma that the prospective of a military defeat eventually produced among many citizens: Their allegiance either to the imagined community of the nation or to an alternative civic community that in the tradition received the name of patria.

True enough, Franco's discourse also spoke of patria, but its meaning related to the tradition of militaristic outlooks, which was not central to the imagined community of exiles and Republicans at large. From a longer-term perspective, Republicans' patriotism as collective identity alternative to nationalism was not triggered anew in the 1936 context; rather, it went back to the 19th century, when patriotic identities recurrently resurfaced in contexts of political crisis that brought about popular mobilizations against authoritarian or instituted corruption (see an example in the 1854 chronicle of the 1854 Revolution in Un Hijo del Pueblo 2018). On their part, the repression of struggles for extending the franchise resulted in recurring dilemmas between remaining or exiling up to the establishment of the democratic republic in $1931 .^{4}$

This whole state of affairs calls for a methodological reassessment. The problem is not in the terminological interchangeability between nation and patria, or of nationalism and patriotism to be found in the sources: It is rather in the conventional practices of experts. In most of modern discourse Patria and nación are terms, but not necessarily concepts, a basic analytical distinction for a minimum methodological bedrock (Gadamer 2000). Beyond that, the case of modern Spain shows that the lexicon of patria extended through Spanish 19th-century texts is of scarce relevance for tracing the semantics of patria as a community of civic referents for citizens committed to defend self-government from the hazards of tyranny or corruption. Actually, a focus on the terminology or the semantics of patria and nación is often misleading for the purpose of accounting for the processes of identification, desidentification, or re-identification with communities of belonging experienced by modern citizens.

4 One final example of relevance in this context was the decision of reputed intellectual Miguel de Unamuno of remaining outside Spain once allowed to return after being forced to exile in 1924 in the wake of the military coup d'état by general Primo de Rivera (Del Arco López 1986). Unamuno would not leave his unforced exile until the proclamation of the Republic in 1931. 
Relying just on what conceptual history offers on this issue (Koselleck 2012) is a self-limiting stake. A distinction between patria or patriotism as terms and as concept is surely mandatory; however, it is also required distinguishing between the wording of patriotism as inserted in the historical record and the category of patriotism as an analytical tool essential for giving meaning to collective identities disengaged from allegiance to modern nations for the sake of civic commitment.

Such methodological reorientation may provide with pathbreaking hypotheses on the rationality of patriotism. From these, the task of the historian is to search for and analyze evidence of such patriotic identity in the historical record. Here, it has been pointed out that the irruption of patriotism strongly relates to contexts that may be defined as a civil war, either by historical actors, the observer, or preferably both. On the other hand, it has also been strongly noted that, paradoxically, discourse revealing patriotic identities may not revolve around the terminology of patria or patriotism. Far from arguing in favor of the imposition of categories from the social sciences on to historical evidence, this methodological stance is committed to recover the experiences of civic subjects at large, and of unforced exiles and in-siles in particular, from current marginalization or misinterpretation.

\section{Conclusions: Pro Patria (Ex Natione) in Exsilium Ire}

It was not by chance that the Spanish Republican exiles captured by the Nazi in France and sent to the concentration camps of Buchenwald and Mauthausen were stamped a blue badge in their clothes that distinguished them from other ideological inmates as "stateless" people (Pike 2009): They figured as expelled from their countries of origin by the new Francoist authorities, a destiny particularly shameful for the nationalist and militaristic culture of their guards. In Spanish language, however, the term for stateless—apátrida, meaning "without a fatherland or country"—, keeps from the original Latin the root patria, signaling the conundrum presented in this text. What Republican exiles had been deprived was actually of a nationality in the legal sense; and yet they were anything but people without patria, in the sense of a community of citizens committed to the reproduction of political virtue: Quite on the contrary, many among them had willingly abandoned their nation of origin precisely for the sake of keeping a sense of belonging to such an imagined community.

Departing from the example of the Spanish Republican exile of 1939, this text has pointed to the limits of the nation as community of belonging and on national identity and nationalism. As much as identity creation, processes of disidentification and re-identification are in themselves political, no matter which referents are involved. However, patriotism stems from processes that are political both in substance and in form. This may be predicated of nationalism as well; however, what is distinctive of patriotism is the relevance of civic consciousness, a moral dimension involved in the experience of disenchantment from national identity as much as in the deliberation for leaving or staying in one's own country of origin, yet an instance that, in requiring active breeding by individuals, also relays on institutional environments suitable for the recreation of political virtue. In this sense, patria is a political community that concurs and combines with the nation, but under circumstances they may compete as incompatible, opposing, even antagonistic referents of belonging. As a final summary, my point would be that the issue of patriotism, apart from the banner "To die for love of the fatherland", can be addressed from the perspective of "To live without the nation" one does not love anymore.

Scholarly production in general, and Spanish post-Francoist historiography in particular, deserve a historiography capable of accounting for this phenomenon and committed to produce discursive evidence of the kind of political emotion involved. However, the issue has wider implications. Beyond nominalist debates, the perspective here offered may help to gain critical distance from current dichotomies on the relations between nationalism and democracy, to which scholars contribute more than usually acknowledged. Just to put an example, in an interview in the media, award-winner Xosé Manuel Núnez Seixas offered a rather normative statement: "We are all nationalists" (Huete 2019). Such an opinion is probably as radical and biased as the alternative urge for embracing cosmopolitanism. The question this article poses is how many so-called nationalists or self-assured cosmopolitans would be willing to abandon their homeland if 
the liberties of their countries happen to be suppressed, or as well how many would remain in their countries but feeling detached from the values of the new anti-democratic legitimacy. For it could be that some among them find out they react like patriots. Better late than never.

Funding: This research was funded by the Project "Aproximación interdisciplinar a los lenguajes jurídico-políticos de la modernidad euroamericana. Dimensiones espacio-temporales", grant number: Mineco HAR2017-84032-P.

Conflicts of Interest: The author declares no conflict of interest.

\section{References}

Abellán, José Luis. 2001. El Exilio como Constante y como Categoría. Madrid: Biblioteca Nueva.

Agamben, Giorgio. 2005. State of Exception. Translated by Kevin Attell. Chicago: The University of Chicago Press. Álvarez Junco, José. 2001. Mater Dolorosa: La Idea de España en el siglo XIX. Madrid: Taurus.

Anderson, Benedict. 1991. Imagined Communities: Reflections on the Origin and Spread of Nationalism. London: Verso. First published 1983.

Armitage, David. 2015. Every Great Revolution Is a Civil War. In Scripting Revolution: A Historical Approach to the Comparative Study of Revolutions. Edited by Keith Michael Baker and Dan Edelstein. Stanford: Stanford University Press, pp. 57-68, 269-71.

Armitage, David. 2017. Civil War: A History in Ideas. New York: Alfred A. Knopf.

Armstrong, John. 1982. Nations before Nationalism. Chapel Hill: University of North Carolina Press.

Aymes, Jean René. 2004. La literatura liberal en la Guerra de la Independencia: Fluctuaciones y divergencias ideológico-semánticas en el empleo de los vocablos 'pueblo', 'patria' y 'nación'. In La ilusión Constitucional: Pueblo, Patria y Nación, de la Ilustración al Romanticismo. Edited by Alberto Ramos Santana. Cádiz: Universidad de Cádiz, pp. $13-41$.

Azaña, Manuel. 1978. Memorias. Madrid: Mondadori.

Ballester Rodríguez, Mateo. 2010. La identidad española en la Edad Moderna (1556-1665). Discursos, Símbolos y Mitos. Madrid: Tecnos.

Banks, Marcus, and Andre Gingrich. 2006. Neo-Nationalism in Europe and Beyond. In Neo-Nationalism in Europe and Beyond: Perspectives from Social Anthropology. New York and Oxford: Berghahn Books, pp. 1-26.

Baron, Alejandro, and Hugo Cuello Díaz. 2016. Podemos and "la patria": Historical Origins, Latin American Influences and Political Uses of the Homeland. Paper Presented at the Conference: The Left and Nationalism in Europe, Centre de recherches politiques de Sciences Po, Paris, June 9-11; Available online: https://www.researchgate.net/publication/308204337_Podemos_and_la_patria_historical_origins_ Latin_American_influences_and_political_uses_of_the_homeland (accessed on 27 November 2019).

Bar-Tal, Daniel, and Ervin Staub. 1999. Patriotism in the Lives of Individuals and Nations. Belmont: Wadsworth Publishing. Beramendi, Justo. 2007. De Provincia a Nación: Historia do Galleguismo Político. Vigo: Edicións Xerais de Galicia.

Borger, Julian. 2019. Donald Trump denounces 'globalism' in nationalist address to UN. The Guardian. September 24. Available online: https://www.theguardian.com/us-news/2019/sep/24/donald-trump-un-address-denouncesglobalism (accessed on 27 November 2019).

Boyd, Carolyn P. 1997. Historia Patria: Politics, History and National Identity in Spain, 1875-1975. Princeton: Princeton University Press.

Brubaker, Rogers. 1999. The Manichean Myth: Rethinking the Distinction Between Civic and Ethnic Nationalism. In Nation and National Identity: TheEuropean Experience in Perspective. Edited by Hanspeter Kriesi Klaus Armington, Hannes Siegrist and Andreas Wimmer. Zurich: Riigger, pp. 55-71.

Bryant, Christopher G. A. 2015. National Art and Britain Made Real: The London 2012 Olympics Opening Ceremony. National Identities 17: 333-46. [CrossRef]

Cabrera, Miguel Ángel. 2004. Post-Social History: An Introduction. Lanham: Lexington Books.

Canal, Jordi. 2000. El carlismo: Dos siglos de contrarrevolución en España. Madrid: Alianza.

Cardim, Pedro, Herzog Tamar, Ruiz Ibáñez, José Javier, and Sabatini Gaetano, eds. 2012. Polycentric Monarchies: How Did Early Modern Spain and Portugal Achive and Maintain a Global Hegemony? Eastbourne: Sussex Academic Press.

Cardoso, Fernando H., and Enzo Faletto. 1979. Dependency and Development in Latin America. New York: Monthly Review Press. 
Carzolio, Ana I. 2002. En los orígenes de la ciudadanía en Castilla: La identidad política del vecino en los siglos XVI y XVI. Hispania 211: 637-92. [CrossRef]

Castro, Américo. 1965. Los Españoles: Cómo Llegaron a Serlo. Madrid: Taurus.

Caudet, Francisco. 2005. El Exilio Republicano de 1939. Madrid: Cátedra.

Chickering, Roger. 2008. The Spanish Civil War in the Age of Total War. In 'If You Tolerate This ... ': The Spanish Civil War in the Age of Total War. Edited by Martin Baumeister and Stefanie Schüler-Springorum. Frankfurt: Campus Verlag, pp. 28-46.

Colley, Linda. 1992. Britons: Forging the Nation, 1707-1837. New Haven: Yale University Press.

Del Arco López, Valentín. 1986. Unamuno frente a Primo de Rivera. De Salamanca al exilio, $1923-1924$. Studia Histórica 4: 129-79.

Durkheim, Emile. 1951. Suicide: A study in Sociology. Glencoe: The Free Press. First published 1897.

Esposito, Roberto. 2011. From the Unpolitical to Biopolitics. Italian Critical Theory 29: 205-13.

Fernández Albaladejo, Pablo. 1997. Católicos antes que ciudadanos: Gestación de una "política española" en los comienzos de la Edad Moderna. In Imágenes de la Diversidad: El Mundo Urbano en la Corona de Castilla (Siglos XVI-XVIII). Edited by José I. Fortea Pérez. Santander: Universidad de Cantabria-Asamblea Regional de Cantabria, pp. 103-28.

Fernández Albaladejo, Pablo. 2007. Materia de España: Cultura, Política e Identidad en la España Moderna. Madrid: Marcial Pons.

Fernández Albaladejo, Pablo. 2017. Review of Herrero. In Repúblicas y republicanismo en la Europa Moderna (siglos XV-XVIII). Edited by Sánchez, Manuel. Madrid: Fondo De Cultura Económica. Cuadernos De Historia Moderna 42: 662-67. Available online: https://doi.org/10.5209/CHMO.58085 (accessed on 1 March 2020).

Fernández Savater, Amador. 2019. Una disputa antropológica: Crisis y movimientos en España, 2008-2017. In España después del 15M. Edited by Jorge Cgaiao y Conde and Isabel Touton. Madrid: La Catarata, pp. 21-38.

Fernández Sebastián, Javier. 2005. Estado, Nación y Patria en el lenguaje político español. Datos lexicométricos y notas para una historia conceptual. Revista de Historia Militar XLIX: 159-219.

Feros, Antonio. 2017. Speaking of Spain: The Evolution of Race and Nation in the Hispanic World. Cambridge: Harvard University Press.

Feros, Antonio. 2019. Antes de España. Nación y Raza en el Mundo Hispánico, 1450-1820. Translated by Pablo Sánchez León. Madrid: Marcial Pons.

Fradera, Josep M. 2015. La Nación Imperial (1750-1914): Derechos, Representación y Ciudadanía en los Imperios de Gran Bretaña, Francia, España y Estados Unidos. Barcelona: Edhasa.

Gadamer, Hans G. 2000. La historia del concepto como filosofía. In Verdad y Método II. Salamanca: Sígueme, pp. 81-93.

García de Cortázar, Fernando. 1994. Historia de España: De Atapuerca al Euro. Barcelona: Planeta.

Gil Pujol, Francisco X. 2004. Un rey, una fe, muchas naciones. Patria y nación en la España de los siglos XVI-XVII. In La Monarquía de las Naciones: Patria, Nación y Naturaleza en la Monarquía de España. Edited by Bernardo García García and Antonio Álvarez-Ossorio. Madrid: Fundación Carlos de Amberes, pp. 39-76.

Gobat, Michel. 2013. The Invention of Latin America: A Transnational History of Anti-Imperialism, Democracy and Race. The American Historical Review 118: 1345-75. [CrossRef]

Godicheau, François. 2014. La Guardia Civil en Cuba, del control del territorio a la guerra permanente (1851-1898). Nuevo Mundo Mundos Nuevos. Available online: http://journals.openedition.org/nuevomundo/67109 (accessed on 27 January 2020).

Gómez Bravo, Gutmaro. 2013. El Exilio Interior: Cárcel Y Represión En La España Franquista (1939-1950). Madrid: Taurus. Hargreaves-Heap, Shaun. 2001. Expressive Rationality: Is Self-Worth just Another Kind of Preference? In The Economic World View: Studies in the Ontology of Economics. Edited by Uskali Mäki. Cambridge: Cambridge University Press, pp. 99-113.

Herrero, Manuel. 2017. La Monarquía Hispánica y las repúblicas europeas. El modelo republicano en una monarquía de ciudades. In Repúblicas y Republicanismo en la Europa Moderna (siglos XVI-XVIII). Edited by Manuel Herrero Sánchez. Madrid: Fondo de Cultura Económica, pp. 273-326.

Herzog, Tamar. 2003. Defining Nations: Immigrants and Citizens in Early Modern Spain and Spanish America. New Haven: Yale University Press.

Huete, Cristina. 2019. "Núñez Seixas: “Todos somos nacionalistas'”. El País. 30/10. Available online: https: //elpais.com/cultura/2019/10/29/actualidad/1572355014_954957.html (accessed on 23 November 2019). 
Huizinga, Johan. 1959. Patriotism and Nationalism in European History. In Men and Ideas. History, the Middle Ages, the Renaissance. Translated by James S. Holmes, and Hans van Marle. New York: Meridian Books, pp. 97-156.

Ilie, Paul. 1981. Literatura y exilio interior. In Escritores Y Sociedad En La España Franquista. Madrid: Fundamentos. Jessop, Bob. 2011. Nation and state. In Introduction to Contemporay European Studies: Concepts in the Context of Globalisation. Edited by Anne S. Krossa. Basingstoke: Palgrave, pp. 168-79.

Johnson, Chalmers. 2004. The Sorrows of Empire: Militarism, Secrecy, and the End of the Republic. New York: Owl Books.

Juaristi, Jon. 1997. El Bucle Melancólico: Historias de Nacionalistas Vascos. Madrid: Espasa.

Kaya, Bülent. 2002. The Changing Face of Europe-Population Flows in the 20th Century. Strasbourg: Council of Europe.

Knight, Alan. 2008. US Imperialism/Hegemony and Latin American Resistance. In Empire and Dissent: The United States and Latin America. Edited by Fred Rosen. Durhan: Duke University Press, pp. 23-52.

Kohn, Hans. 1946. The Idea of Nationalism. A Study in its Origins and Background. New York: Macmillan.

Koselleck, Reinhart. 2012. Patriotismo. Fundamentos y límites de un concepto moderno. In Historias de Conceptos. Estudios Sobre Semántica y Pragmática del Lenguaje Político y Social. Madrid: Trotta, pp. 141-60.

Lessafer, Randall. 2001. European Legal History: A Cultural and Political Perspective. Nueva York: Cambridge University Press.

Loureiro, Ángel G. 2000. The Ethics of Autobiography: Replacing the Subject in Modern Spain. Nashville: Valderbilt University Press.

MacIntyre, Alisdair. 1995. Is Patriotism a Virtue? In Theorizing Citizenship. Edited by Ronald Beiner. New York: State University of New York Press, pp. 209-28.

MacPherson, Alan. 2006. Antiyanquismo: Nascent Scholarship, Ancient Sentiments". In Anti-Americanisn in Latin America and the Caribbean. Edited by Alan MacPherson. New York and Oxford: Berghahn Books, pp. 1-37.

Mazlish, Bruce. 2004. Civilization and Its Contents. Stanford: Stanford University Press.

Merton, Robert K. 1938. Social Structure and Anomie. American Sociological Review 3: 672-82. [CrossRef]

Morales Moya, Antonio. 2013. La formación histórica de España: La polémica entre Américo Castro y Claudio Sánchez-Albornoz. In Historia de la Nación y del Nacionalismo Español. Edited by Antonio Morales Moya, Juan Pablo Fusi and Andrés de Blas Guerrero. Madrid: Galaxia Gutenberg, pp. 364-89.

Moscoso, Leopoldo A., and Pablo Sánchez León. 2017. Encrucijadas del entusiasmo: La transmisión de la identidad revolucionaria, 1789-1917. In 1917. La Revolución Rusa cien años después. Edited by Juan Andrade and Fernando Hernández Sánchez. Madrid: Akal, pp. 53-82.

Mouffe, Chantal. 1999. Deliberative Democracy or Agonistic Pluralism. Social Research 66: 745-58.

Núñez Seixas, Xosé M. 2006. ¡Afuera el Invasor! Nacionalismos y Movilización Bélica en la Guerra Civil Española (1936-1939). Madrid: Marcial Pons.

Núñez Seixas, Xosé M. 2014. Lo regional y lo local en el primer franquismo. In Imaginarios y Representaciones de España Durante el Franquismo. Edited by Stephane Micchonneau and Xosé Manuel Núñez Seixas. Madrid: Casa de Velázquez, pp. 127-54.

Núñez-Seixas, José M. 2018. Suspiros de España: El Nacionalismo Español, 1808-2018. Barcelona: Crítica.

Nussbaum, Martha C. 1989. Patriotism and Cosmopolitanism. In For Love of Country? Debating the Limits of Patriotism. Edited by Joshua Cohen. Boston: Beacon Press, pp. 3-20.

Nussbaum, Martha C. 2019. The Cosmopolitan Tradition: A Noble but Flawed Ideal. Cambridge and London: Belknap Press.

Oller, Josep M., Albert Satorra, and Adolf Tobeña. 2019. Secessionists vs. Unionists in Catalonia: Mood, Emotional Profiles and Beliefs about Secession Perspectives in Two Confronted Communities. Psychology 10: 336-57. [CrossRef]

Pérez Vejo, Tomás. 2015. España Imaginada: Historia de la Invención de una Nación. Madrid: Galaxia Gutenberg.

Pike, David W. 2009. Spaniards in the Holocaust: Mauthausen, Horror on the Danube. London and New York: Routledge.

Pizzorno, Alessandro. 1986. Some Other Kind of Otherness: A Critique of 'Rational Choice' Theories. In Development, Democracy, and the Art of Tresspassing. Essays in honor of Albert O. Hirschman. Edited by Alejandro Foxley, Michael S. MacPherson and Guillermo O’Donnell. Notre Dame: University of Notre Dame Press, pp. 355-73.

Pocock, John G. A. 1975. The Machiavellian Moment. Florentine Politics and the Atlantic Republican Tradition. Princeton: Princeton University Press.

Portillo, José M. 2000. Revolución de Nación. Orígenes de la Cultura Constitucional en España, 1780-1808. Madrid: Centro de Estudios Políticos y Constitucionales. 
Prak, Maarten. 2018. Citizens without Nations: Urban Citizenship in Europe and the World, c. 1000-1789. Cambridge: Cambridge University Press.

Primoratz, Igor. 2002. Patriotism. Washington: Humanity Books.

Renaut, Alain. 1991. Logiques de la nation. In Théories du Nationalisme. Nation, Nationalité, Ethnicité. Edited by Gil Delannoi and Pierre-André Taguieff. Paris: Kimé, pp. 29-46.

Salabert, Miguel. 1988. El exilio interior. Barcelona: Anthropos.

Sánchez León, Pablo. 2001. Town and Country in Early Modern Castile, 1400-1650. In Town and Country in Early Modern Europe. Edited by Stephen R. Epstein. Cambridge: Cambridge University Press, pp. 272-91.

Sánchez León, Pablo. 2002. La constitución histórica del sujeto comunero: Orden absolutista y lucha por la incorporación estamental en las ciudades de Castilla, 1350-1520. In Actas del Congreso Internacional "En torno a las Comunidades de Castilla. Edited by Fernando Martínez Gil. Cuenca: Universidad de Castilla-La Mancha, pp. 159-208.

Sánchez León, Pablo. 2007. Changing Patterns of Urban Conflict in Late Medieval Castile. Past and Present 195: 217-32. [CrossRef]

Sánchez León, Pablo. 2008. La "guerra civil" de 1808. El 2 de Mayo en la cultura liberal española. In La Guerra de la Independencia en la Cultura Española. Edited by J. Álvarez Barrientos. Madrid: Siglo XXI, pp. 79-101.

Simal, Juan L. 2012. Emigrados: España y el Exilio Internacional, 1814-1834. Madrid: Centro de Estudios Políticos y Constitucionales.

Smith, Anthony. 1991. National Identity. London: Penguin Books.

Smith, Anthony D. 2000. The Nation in History: Historiographical Debates about Ethnicity and Nationalism. Hanover: University Press of New England.

Sola, Jorge, and César Rendueles. 2018. Podemos, the Upheaval of Spanish Politics and the Challenge of Populism. Journal of Contemporary European Studies 26: 99-116. [CrossRef]

Tamir, Yael. 1997. Pro patria mori! Death and the State. In The Morality of Nationalism. Edited by R. McKim and J. McMaham. Oxford and New York: Oxford University Press, pp. 227-41.

Taylor, Charles. 1989. Why Democracy Needs Patriotism. In For Love of Country? Edited by J. Cohen. Boston: Beacon Press, pp. 119-21.

Traverso, Enzo. 2016. Fire and Blood: The European Civil War, 1914-1945. London: Verso.

Un Hijo del Pueblo. 2018. Las Jornadas de Julio [1854] (Una Crónica Anónima de otro 15-M en el Pasado Ciudadano Español). Edited by Pablo Sánchez León. Madrid: Postmetropolis editorial.

Valdeón Baruque, Julio. 1982. Las Raíces Medievales de España. Madrid: Real Academia de la Historia.

Varela, Javier. 1994. Nación, patria y patriotismo en los orígenes del nacionalismo español. Studia Histórica Historia contemporánea XII: 31-43.

Veblen, Thorstein. 1917. An Inquiry into the Nature of Peace and the Terms of Its Perpetuation. London: MacMillan.

Vilar, Pierre. 1982. Patria y nación en el vocabulario de la guerra de Independencia. In Hidalgos, Amotinados y Guerrilleros: Pueblos y Poderes en la Historia de España. Barcelona: Crítica, pp. 211-52.

Viroli, Maurizio. 1992. From Politics to Reason of State: The Acquisition and Transformation of the Language of Politics, 1250-1600. New York: Cambridge University Press.

Viroli, Maurizio. 1995. For Love of Country: An Essay on Patriotism and Nationalism. Oxford: Oxford University Press.

Viroli, Maurizio. 2001. El sentido olvidado del patriotismo republicano. Isegoría 24: 5-14. [CrossRef]

Wulff, Fernando. 2003. Las Esencias Patrias: Historiografía e Historia Antigua en la Construcción de la Identidad Española (Siglos XVI-XX). Barcelona: Crítica.

(C) 2020 by the author. Licensee MDPI, Basel, Switzerland. This article is an open access article distributed under the terms and conditions of the Creative Commons Attribution (CC BY) license (http://creativecommons.org/licenses/by/4.0/). 